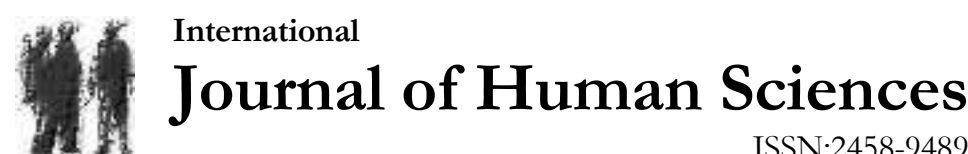

Volume: 19 Issue: 1 Year: 2022

\section{The relationship between postpartum social support and attitudes towards breastfeeding: A cultural perspective ${ }^{1}$}

\author{
Esra Karataş Okyay ${ }^{2}$ \\ Zeliha Sunay ${ }^{3}$ \\ Sidıka Özlem Cengizhan ${ }^{4}$ \\ Hülya Kamalak ${ }^{5}$ \\ Tuba Uçar ${ }^{6}$
}

\begin{abstract}
Aim: This study intends to provide an analysis of the relationship between postpartum social support and women's breastfeeding attitudes from different cultural perspectives. Method: This study was conducted between April-September 2019. The study population comprised of 430 women with 4-24 week old babies who visited health centers in the provinces of Adiyaman (Region 1), Kahramanmaraş (Region 2) and Malatya (Region 3). Findings: The mean scores of women from the BAES were 105.54 \pm 13.16 in Region 1, $103.30 \pm 15.77$ in Region 2, and $99.46 \pm 13.47$ in Region $3(\mathrm{P}<0.05)$. The mean scores of women from the "Importance of the Need" subscale on

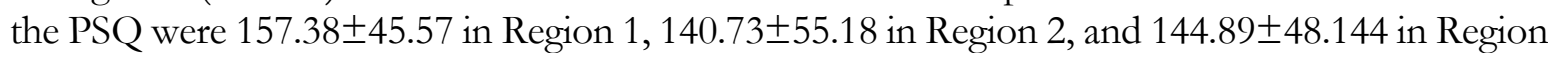
3 ( $<<0.05)$.The mean scores of women from the "Support Received" subscale on the PSQ were 112.39 \pm 51.58 in Region 1; $116.87 \pm 52.69$ in Region 2, and 108.89 \pm 50.79 in Region 3 (P>0.05).In Region 2, a significant and positive correlation was found between the subscales "Importance of the Need" and the "Perceived Support" on the BAES and the PSQ ( $r=0.259, r=0.255, P<0.05$, respectively). Conclusion: A comparison of the relationship between postpartum social support and attitudes towards breastfeeding revealed major differences between the Regions.
\end{abstract}

Keywords: Postpartum; breastfeeding attitudes; social support; culture; midwifery.

\footnotetext{
1 This research was presented as an oral presentation at the 1st International Midwifery Education Research and Development (EBEARGE) Congress held in Izmir on 7-9 November 2018.

2 Research Assistant, Department of Midwifery, Faculty of Health Sciences, İnönü University, esrakaratas44@hotmail.com (10) ORCID: 0000-0002-6443-8277

3 Research Assistant, Department of Midwifery, Faculty of Health Sciences, Munzur University, zelihasunay@munzur.edu.tr (D) ORCID: 0000-0001-9375-4300

${ }^{4}$ Midwife, Number 15 Health Center, sidika cengizhan@hotmail.com (1) ORCID: 0000-0002-6546-4282

${ }^{5}$ Midwife, Dağdalı Health Center, hulyakoca31@,windowslive.com (10) ORCID:0000-0002-7418-0775

${ }^{6}$ Associate Professor, Department of Midwifery, Faculty of Health Sciences, İnönü University, tuba.ucar@inonu.edu.tr (1D) ORCID: 0000-0002-4450-6826
} 
Karataş Okyay, E., Sunay, Z., Cengizhan, S. Ö., Kamalak, H., \& Uçar, T. (2022). The relationship between postpartum social support and attitudes towards breastfeeding: A cultural perspective. Journal of Human Sciences, 19(1), 17-26. doi:10.14687/ihs.v19i1.6050

\section{Introduction}

Whether or not a mother has access to social support after childbirth is crucial for adapting to and coping with this challenging process. The term "social support" is used to refer to the help and assistance mothers usually get following childbirth, generally from their close circle, with carrying out tasks like caring for the baby or doing the household chores. It also involves emotional support (Aksakalli et al., 2012). Social support is extremely important in terms of helping a mother embrace the role of motherhood as well as ensuring the well-being and healthy nutrition of the new-born (1). Whilst not having ample social support after delivery may cause a number of inconveniences for the mother and the new-born (Leveno \& Cunningham, 2004), it might also produce negative consequences with regards to the mother's attitude towards breastfeeding (Çelebioğlu et al., 2006; İnce et al., 2010)

Post-delivery social support ideally starts when a mother starts breastfeeding her baby (Area, 2011). Several studies have reported that getting social support after child delivery influences attitudes towards breastfeeding (Gangle \& Bedwei-Majdoub, 2020; Hongo et al., 2020; Jackson \& Hallam, 2020). According to various studies, breastfeeding is not only an instinctive behaviour; but rather the product of a confluence of individual, family-related and social factors (Kong\&Lee, 2004; Özkan et al., 2006; Gölbaşı \& Koç, 2008; Özer et al., 2010; Annagür \& Annagür, 2012). It has been reported that a mother's willingness to breastfeed her child is influenced by personal traits and attitudes, such as a lack of self-confidence, as well as by socio-demographic characteristics. Also, factors like a mother's access to means of social support; traditional beliefs and discourses surrounding breastfeeding; a mother's belief or disbelief in her breastmilk, her anxieties and physical problems affecting a mother's breasts are reported to have a role in shaping attitudes towards breastfeeding (Gölbaş1 \& Koç, 2008; Tezcan, 2005; Knaak,2006; Kruse et al., 2006).

In recent years, there has been a growing amount of awareness about the relationship between postpartum support, that is vital for the mother and the baby, and breastfeeding. However, the nature of that awareness varies across different cultures and societies. In Turkey, more studies are needed that can offer new perspectives on the relationship between postpartum social support and breastfeeding attitudes. In this context, any plan for the provision of breastfeeding-related services through the agency of midwives should take into account the social support systems available for women, the dominant breastfeeding attitudes as well as the cultural variations and idiosyncrasies. This study intends to demonstrate the relationship between postpartum social support and breastfeeding attitudes from various cultural perspectives.

\section{Purpose}

The aim of this study was to determine the relationship between postpartum social support and breastfeeding attitudes from various cultural perspectives.

\section{Method and Material}

Descriptive and comparative, this multi-centred research study was conducted between AprilSeptember 2019 in the following provinces: Adiyaman (Region 1), a city in Southeastern Anatolia; Kahramanmaraş, (Region 2) a city in the Mediterranean Region and Malatya (Region 3), a city in Eastern Anatolia. The study population comprised of women with 4-24 week old babies registered in the following heath centres in Adiyaman (Region 1), Kahramanmaraş (Region 2) and Malatya (Region 3).

The power analysis showed that the least number of respondents required to achieve a $5 \%$ margin of error, 95\% confidence interval on a two-sided level of significance and an $80 \%$ sample power was three hundred and forty-six. 
Karataş Okyay, E., Sunay, Z., Cengizhan, S. Ö., Kamalak, H., \& Uçar, T. (2022). The relationship between postpartum social support and attitudes towards breastfeeding: A cultural perspective. Journal of Human Sciences, 19(1), 17-26. doi:10.14687/ihs.v19i1.6050

Four hundred and thirty women (Adiyaman $n=157$, Kahramanmaraş $n=150$, Malatya $n=123$ ) who agreed to participate in the study between the data collection dates were reached. Women who for any reason visited the identified Family Health / Community Health Centres and met the criteria for inclusion in the study were recruited via improbable random sampling.

\subsection{Inclusion criteria}

- Being over eighteen years of age,

- Not having problems with communicating with others,

- No postpartum complications affecting the new-born and the mother (such as preterm labour, foetal anomaly, bleeding, infection etc.)

\subsection{Exclusion criteria}

-Women who have been previously diagnosed with depression and / or who take a psychiatric drug.

\subsection{Data Collection Tools:}

The data were collected by the researchers using the face-to-face method in the training rooms of the centres, using the personal information form, the Breastfeeding Attitude Evaluation Scale and the Postpartum Support Questionnaire.

3.3.1. Personal Information Form: The form was put together by researchers on the basis of other studies in the literature to capture some of the personal traits of the female subjects (Aksakalli et al., 2012; Gölbaş1 \& Koç, 2008;Güney \& Uçar, 2018). It contains 16 questions concerning the sociodemographic characteristics (age, educational level, employment status, family type), obstetric history (number of pregnancies, number of living children and miscarriages) and the breastfeeding attitudes of women.

3.3.2. Breastfeeding Attitude Evaluation Scale (BAES): It is a 5-point Likert scale consisting of 46 questions developed by Arslan Özkan in 1999 to assess the attitudes of new mothers towards breastfeeding (Özkan, 2015).

The scale intends to provide an analysis of attitudes on the basis of the mother's own attitude towards breastfeeding; the mother's attitude towards breastfeeding in relation to others (her partner, family members, close circle of friends, healthcare staff); and the society's attitudes towards breastfeeding. The scale contains twenty-two items with positive attitudes and twenty-four items with negative attitudes towards breastfeeding. The highest score that can be achieved on this scale is one hundred and eighty-four. Respondents could get eighty-eight points from items containing positive attitudes as opposed to ninety-four points from items containing negative attitudes. The higher the score from the scale, the more positive a mother's attitude toward breastfeeding. The scale's Cronbach's alpha value was 0.63 (18). This study also found that the scale's Cronbach's alpha value was 0.63 .

3.3.3. Postpartum Support Questionnaire (PSQ) : The scale was developed by Logsdon et al. in 1996 to measure the extend of the social support women get after delivery; Turkish version of scale was validated by Ertürk in 2007 (Logsdon et al.,1996; Ertürk, 2007). The scale was specifically designed to measure the extent to which women are able to adapt to the role of motherhood in the postpartum period and it has two subscales, namely "the importance of the need" and the "support received" to satisfy this need. Easy to read and comprehend, it is an 8-point Likert scale with thirtyfour items that has a score range of 0 to 7 where 0 means "Not important" and 7 means "Very important". There are separate questions for the two subscales in the scale by answering which the respondents get different scores. The scoring rationale dictates that the higher score from the two subscales, the higher the significance of the need and the higher the level of support received. From the "importance of the need" subscale, respondents can get scores in the ranges of "130 and below"; "131-150" and "151 and above". Accordingly, for women scoring 130 points and below, the need for postpartum support is "not important"; for women scoring between 131-150 points it is "important" and for women scoring 151 points and above, it is "very important". From the "support received" subscale, respondents can get scores in the ranges of "99 points and below", "100-134 points" and "135 points and above". Accordingly, for women scoring 99 points and below, there is 
Karataş Okyay, E., Sunay, Z., Cengizhan, S. Ö., Kamalak, H., \& Uçar, T. (2022). The relationship between postpartum social support and attitudes towards breastfeeding: A cultural perspective. Journal of Human Sciences, 19(1), 17-26. doi:10.14687/ihs.v19i1.6050

"no postpartum support"; for women scoring between 100- 134 points, there is "postpartum support" and for women scoring 135 points and above there is "more than enough postpartum support". The Cronbach's alpha coefficient for the "importance of the need" subscale was 0.88 ; while the Cronbach's alpha coefficient for the "support received" subscale was 0.95 (20). In this study, the Cronbach's alpha coefficient for the "importance of the need" subscale was 0.95 while it was 0.96 for the "support received" subscale.

\subsection{Data analysis}

SPSS 25.0 for Windows was used for statistical analysis of the data obtained. Besides descriptive statistics (number, percentage, mean, standard deviation), the Chi-square test was used to compare categorical data; the one-way analysis of variance was used to compare the mean values of scales between Regions, and lastly, the Pearson correlation analysis was used to assess the relationship between scales. The Tukey's test was also used in terms of a post-hoc test to determine between which Regions there was a significant difference.

\subsection{Ethical principles}

Prior to conducting the study, the approval (Decision No. 2018 / 12-14) of the Ethics Committee for Scientific Research and Publication of the Health Sciences Department of İnönü University was taken as well as the consent of the concerned authorities. Also, verbal consent was taken from all respondents.

\section{Results}

For the study, four hundred and thirty females (Region $1 \mathrm{n}=157$, Region $2 \mathrm{n}=150$, Region $3 \mathrm{n}=123$ women) in the postpartum period were recruited. Table 1 illustrates the distribution of Introductory and Obstetric Characteristics of Women. The mean age of women were $30.58 \pm 5.57$ in Region 1; $28.13 \pm 5.47$ in Region 2; and $28.73 \pm 5.12$ in Region 3. Of the respondents in Region 1, Region 2, Region 3; $39.5 \%, 44.7 \%$, and $39.0 \%$ had a secondary school degree, respectively; while $76.4 \%, 74.0 \%$, and $65.9 \%$ were unemployed, again respectively. It was found that $54.1 \%$ of women in Region 1 earned less than they spent; while $67.3 \%$ and $63.4 \%$ of women in Region 2 and 3 respectively earned just enough to cover their expenses (Table 1).

The length of time that transpired after birth was $6.89 \pm 3.40$ weeks in Region 1; $8.33 \pm 5.56$ weeks in Region 2 and $10.01 \pm 6.15$ weeks in Region 3. Of the respondents in Region 1, Region 2, Region 3; 75.2\%, 70.7\%, and $61.0 \%$ were multiparous, respectively; also, $45.2 \%$ of respondents in Region 1 had three children and above, while $43.3 \%$ and $48.8 \%$ of respondents in Region 2 and 3 had one child, respectively (Table 1).

Table 1. Distribution of introductory and obstetric characteristics of women ( $\mathrm{n}=430)$

\begin{tabular}{lcccccc}
\hline \multirow{2}{*}{ Characteristics } & \multicolumn{2}{c}{$\begin{array}{c}\text { Region } \mathbf{1} \\
(\mathbf{n = 1 5 7 )}\end{array}$} & \multicolumn{2}{c}{$\begin{array}{c}\text { Region 2 } \\
(\mathbf{n = 1 5 0 )}\end{array}$} & \multicolumn{2}{c}{$\begin{array}{c}\text { Region 3 } \\
(\mathbf{n = 1 2 3})\end{array}$} \\
\cline { 2 - 8 } & $\mathbf{n}$ & $\mathbf{0}$ & $\mathbf{n}$ & $\mathbf{0}$ & $\mathbf{n}$ & $\mathbf{\%}$ \\
\hline Age (years) (mean $\pm \mathrm{SD})$ & $30.58 \pm 5.57$ & $28.13 \pm 5.47$ & $28.73 \pm 5.12$ \\
\hline Education level & 10 & 6.4 & 5 & 3.3 & 2 & 1.6 \\
Illiterate & 6 & 3.8 & 2 & 1.3 & 6 & 4.9 \\
Literate only & 42 & 26.8 & 28 & 18.7 & 16 & 13.0 \\
Primary school & 62 & 39.5 & 67 & 44.7 & 48 & 39.0 \\
High school & 37 & 23.6 & 48 & 32.0 & 51 & 41.5 \\
University & & & & & & \\
\hline
\end{tabular}


Karataş Okyay, E., Sunay, Z., Cengizhan, S. Ö., Kamalak, H., \& Uçar, T. (2022). The relationship between postpartum social support and attitudes towards breastfeeding: A cultural perspective. Journal of Human Sciences, 19(1), 17-26. doi:10.14687/jhs.v19i1.6050

\begin{tabular}{|c|c|c|c|c|c|c|}
\hline \multicolumn{7}{|l|}{ Working status } \\
\hline Working & 8 & 5.1 & 23 & 15.3 & 13 & 10.6 \\
\hline Not working & 120 & 76.4 & 111 & 74.0 & 81 & 65.9 \\
\hline On maternity leave & 29 & 18.5 & 16 & 10.7 & 29 & 23.6 \\
\hline \multicolumn{7}{|l|}{ Profession } \\
\hline Officer & 25 & 67.6 & 28 & 71.8 & 33 & 78.6 \\
\hline Worker & 5 & 13.5 & 9 & 23.1 & 7 & 16.7 \\
\hline Self- employment & 7 & 18.9 & 2 & 5.1 & 2 & 4.8 \\
\hline \multicolumn{7}{|l|}{ Social security } \\
\hline Yes & 130 & 82.8 & 142 & 94.7 & 111 & 90.2 \\
\hline No & 27 & 17.2 & 8 & 5.3 & 12 & 9.8 \\
\hline \multicolumn{7}{|l|}{ Income level } \\
\hline Low & 85 & 54.1 & 29 & 19.3 & 26 & 21.1 \\
\hline Medium & 59 & 37.6 & 101 & 67.3 & 78 & 63.4 \\
\hline High & 13 & 8.3 & 20 & 13.3 & 19 & 15.4 \\
\hline \multicolumn{7}{|l|}{ Family type } \\
\hline Nuclear & 132 & 84.1 & 129 & 86.0 & 102 & 82.9 \\
\hline Traditional & 24 & 15.3 & 20 & 13.3 & 19 & 15.4 \\
\hline Broken & 1 & 0.6 & 1 & 0.7 & 2 & 1.6 \\
\hline $\begin{array}{l}\text { Number of weeks after birth } \\
(\text { mean } \pm \text { SD) }\end{array}$ & \multicolumn{2}{|c|}{$6.89 \pm 3.40$} & \multicolumn{2}{|c|}{$8.33 \pm 5.56$} & \multicolumn{2}{|c|}{$10.01 \pm 6.15$} \\
\hline \multicolumn{7}{|l|}{ Parity } \\
\hline Primigravida & 39 & 24.8 & 44 & 29.3 & 48 & 39.0 \\
\hline Multigravida & 118 & 75.2 & 106 & 70.7 & 75 & 61.0 \\
\hline \multicolumn{7}{|l|}{ Abortion } \\
\hline No & 107 & 68.2 & 107 & 71.3 & 84 & 68.3 \\
\hline 1 & 41 & 26.1 & 36 & 24.0 & 33 & 26.8 \\
\hline 2 and above & 9 & 5.7 & 7 & 4.7 & 6 & 4.9 \\
\hline \multicolumn{7}{|l|}{ Number of children living 1} \\
\hline 2 & 45 & 28.7 & 65 & 43.3 & 60 & 48.8 \\
\hline \multirow[t]{2}{*}{3 and above } & 41 & 26.1 & 42 & 28.0 & 40 & 32.5 \\
\hline & 71 & 45.2 & 43 & 28.7 & 23 & 18.7 \\
\hline
\end{tabular}

Table 2 contains certain comparison of some postpartum traits of women and PSQ Subscale categories by Regions. This study found that $42.1 \%$ of mothers in Region 2 breastfed their babies within the first hour, the highest rate of all Regions, and also that the difference between the Regions was statistically significant $(\mathrm{P}<0.05)$. It was also established that $37.2 \%$ of mothers in Region 2 exclusively breastfed their babies, the highest rate of all Regions ( $\mathrm{P}>0.05)$ with $36.8 \%$ of mothers in Region 1, also the highest rate of all Regions, responding to the question why they chose not to exclusively breastfeed their baby by stating that their breastmilk was not enough ( $P>0.05)$. A Regionbased comparison of the extent of the postpartum support received by the mothers revealed that $37.5 \%$ of mothers in Region 2 had received postpartum support, the highest rate of all Regions, while only $26.0 \%$ of mothers in Region 3 had received postpartum support, the lowest of all Regions. The difference between the Regions was statistically significant $(\mathrm{P}<0.05)$. Concerning who provided mothers with postpartum support, mothers/ mothers-in-law accounted for $42.2 \%$ of the supportgivers in Region 2, putting them in the first place, while spouses/partners accounted for $35.8 \%$ of the support-givers in Region 1, putting them in the first place. The difference between the Regions was statistically significant $(\mathrm{P}<0.05)$ (Table 2$)$. 
Karataş Okyay, E., Sunay, Z., Cengizhan, S. Ö., Kamalak, H., \& Uçar, T. (2022). The relationship between postpartum social support and attitudes towards breastfeeding: A cultural perspective. Journal of Human Sciences, 19(1), 17-26. doi:10.14687/jhs.v19i1.6050

Comparing the "importance of the need" subscale on the PSQ across three Regions, 42.9\% of the respondents in Region 2 responded that postpartum support was not important; $40.2 \%$ of the respondents in Region 1 responded that it was very important while 39.3\% of the respondents in Region 3 responded that it was important. The difference between the Regions was statistically significant $(\mathrm{P}<0.05)$. Comparing the "support received" subscale on the PSQ across three Regions, $45.1 \%$ of the respondents in Region 1 received support, the highest of all Regions, while only $34.1 \%$ of the respondents in Region 3 received support, the lowest of all Regions. The difference between the Regions was statistically significant $(\mathrm{P}<0.05)$ (Table 2 ).

Table 2. Comparison of some postpartum traits of women and PSQ sub-scale categories by

\begin{tabular}{|c|c|c|c|c|c|c|c|}
\hline \multirow[t]{2}{*}{ Variables } & \multicolumn{2}{|c|}{$\begin{array}{c}\text { Region } 1 \\
(n=157)\end{array}$} & \multicolumn{2}{|c|}{$\begin{array}{c}\text { Region } 2 \\
(n=150)\end{array}$} & \multicolumn{2}{|c|}{$\begin{array}{c}\text { Region } 3 \\
(n=123)\end{array}$} & \multirow[t]{2}{*}{$\begin{array}{l}\text { Statistical } \\
\text { Analysis }\end{array}$} \\
\hline & $\mathbf{n}$ & $\%$ & $\mathbf{n}$ & $\%$ & $\mathbf{n}$ & $\%$ & \\
\hline \multicolumn{8}{|l|}{ First breastfeeding time } \\
\hline 1 st hour & 116 & 36.1 & 135 & 42.1 & 70 & 21.8 & $X^{2}=46.34$ \\
\hline 2 st hour & 19 & 31.1 & 15 & 24.6 & 27 & 44.3 & $P<0.001$ \\
\hline 3 st hour and after & 22 & 45.8 & 0 & 0.0 & 26 & 54.2 & \\
\hline \multicolumn{8}{|l|}{ Baby's feeding type } \\
\hline Only breast milk & 120 & 36.0 & 124 & 37.2 & 89 & 26.7 & $X^{2}=8.48$ \\
\hline Only mama & 1 & 10.0 & 5 & 50.0 & 4 & 40.0 & $P=0.075$ \\
\hline Breast milk + mama & 36 & 41.4 & 21 & 24.1 & 30 & 34.5 & \\
\hline \multicolumn{8}{|l|}{ Reason for not just breastfeeding } \\
\hline Breast milk is not enough & 32 & 36.8 & 25 & 28.7 & 30 & 34.5 & $\mathrm{X}^{2}=10.61$ \\
\hline Because I work & 0 & 0 & 0 & 0 & 2 & 100 & $P=0.101$ \\
\hline Difficulty sucking / breast rejection & 5 & 2.9 & 1 & 12.5 & 2 & 25.0 & \\
\hline \multicolumn{8}{|l|}{ Postpartum support availability } \\
\hline Yes & 141 & 36.0 & 147 & 37.5 & 104 & 26.5 & $X^{2}=15.73$ \\
\hline No & 16 & 42.1 & 3 & 7.9 & 19 & 50.0 & $P<0.001$ \\
\hline \multicolumn{8}{|l|}{ Postpartum support person } \\
\hline Mother / mother-in- law & 67 & 27.5 & 103 & 42.2 & 74 & 30.3 & $X^{2}=23.66$ \\
\hline Spouse & 36 & 44.4 & 29 & 35.8 & 16 & 19.8 & $P<0.001$ \\
\hline Sister/Friend & 38 & 56.7 & 15 & 22.4 & 14 & 20.9 & \\
\hline \multicolumn{8}{|l|}{ PSQ 1mportance needs dimension } \\
\hline Need for support does not matter need & 41 & 29.3 & 60 & 42.9 & 39 & 27.9 & $X^{2}=11.80$ \\
\hline for support is important & 24 & 39.3 & 13 & 21.3 & 24 & 39.3 & $P=0.019$ \\
\hline Need for support is very $1 \mathrm{mportant}$ & 92 & 40.2 & 77 & 33.6 & 60 & 26.2 & \\
\hline \multicolumn{8}{|l|}{ PSQ support dimension } \\
\hline No support & 65 & 36.9 & 51 & 29.0 & 60 & 34.1 & $\mathrm{X}^{2}=11.91$ \\
\hline Have support & 41 & 45.1 & 28 & 30.8 & 22 & 24.2 & $P=0.018$ \\
\hline Support too much & 51 & 31.3 & 71 & 43.6 & 41 & 25.2 & \\
\hline
\end{tabular}

PSQ: Postpartum Support Questionnaire

Table 3 contains a comparison of mean scores from the PSQ and the BAES. Regarding the score averages of the respondents from the BAES, it was $105.54 \pm 13.16$ in Region 1; $103.30 \pm 15.77$ in Region 2 and $99.46 \pm 13.47$ in Region 3, and the difference between the Regions was statistically significant $(\mathrm{P}<0.05)$. According to the post-hoc test done, the difference between the Regions was 
Karataş Okyay, E., Sunay, Z., Cengizhan, S. Ö., Kamalak, H., \& Uçar, T. (2022). The relationship between postpartum social support and attitudes towards breastfeeding: A cultural perspective. Journal of Human Sciences, 19(1), 17-26. doi:10.14687/ihs.v19i1.6050

found to emanate from that between Region 1 and Region 3. $(\mathrm{a}>\mathrm{c})$. The mean scores of the respondents from the "Importance of the Need" subscale on the PSQ were 157.38 \pm 45.57 in Region $1, ; 140.73 \pm 55.18$ in Region 2, and 144.89 \pm 48.144 in Region 3 and the difference between the Regions was statistically significant $(\mathrm{P}<0.05)$. According to the post-hoc test done, the difference between the Regions was found to emanate from that between Region 1 and Region $2(a>b)$. The mean scores of the respondents from the "Support Received" subscale on the PSQ were 112.39 \pm 51.58 in Region 1; 116.87 \pm 52.69 in Region 2, and 108.89 \pm 50.79 in Region 3 and the difference between the Regions was not statistically significant $(\mathrm{P}<0.05)$ (Table 3).

Table 3. Comparison of women's PSQ and BAES scores $(n=430)$

\begin{tabular}{|c|c|c|c|c|c|}
\hline Scales & $\begin{array}{c}\text { Region } 1 \\
(\mathrm{n}=157)\end{array}$ & $\begin{array}{c}\text { Region } 2 \\
(\mathrm{n}=150)\end{array}$ & $\begin{array}{c}\text { Region } 3 \\
(\mathrm{n}=123)\end{array}$ & $\begin{array}{c}\text { Statistical } \\
\text { Analysis }\end{array}$ & Meaningfulness \\
\hline BAES & $105.54 \pm 13.16^{\mathrm{a}}$ & $103.30 \pm 15.77^{\mathrm{b}}$ & $99.46 \pm 13.47^{c}$ & $\begin{array}{l}\mathrm{F}=6.366 \\
P=0.002\end{array}$ & $a>c$ \\
\hline $\begin{array}{l}\text { PSQ- } \\
\text { your need } \\
\text { is } \\
\text { important }\end{array}$ & $157.38 \pm 45.57^{\mathrm{a}}$ & $140.73 \pm 55.18^{b}$ & $144.89 \pm 48.14^{c}$ & $\begin{array}{l}\mathrm{F}=4.620 \\
P=0.010\end{array}$ & $a>b$ \\
\hline $\begin{array}{l}\text { PSQ- } \\
\text { support } \\
\text { received }\end{array}$ & $112.39 \pm 51.58$ & $116.87 \pm 52.69$ & $108.89 \pm 50.79$ & $\begin{array}{l}\mathrm{F}=0.818 \\
P=0.442\end{array}$ & \\
\hline
\end{tabular}

Table 3 illustrates the association between the subscales of the BAES and the PSQ across three Regions covered in the study. In Region 2, a significant and positive correlation was found between the subscales "Importance of the Need" and the "Perceived Support" on the BAES and the PSQ ( $r=0.259, \mathrm{P}<0.01 ; \mathrm{r}=0.255, \mathrm{P}<0.01$, respectively). It was also found that there was no statistically significant relationship between the subscales of the BAES and the PSQ in Region 1 and Region 3 (Table 4). Finally, there was no statistically significant relationship between the subscales of the BAES and the PSQ in Region 1 and Region 3 (Table 4).

Table 4. The relationship between BAES and PSQ subscales in three regions

\begin{tabular}{llc}
\hline Regions & PSQ Sub-scales & BAES \\
& & $\mathbf{r}$ \\
\hline Region 1 $(\mathrm{n}=157)$ & PSQ-The importance of need & -0.108 \\
& PSQ-Received support & 0.003 \\
Region 2 ( $\mathrm{n}=150)$ & PSQ-The importance of need & $0.259^{*}$ \\
& PSQ-Received support & $0.255^{*}$ \\
Region 3 ( $\mathrm{n}=123)$ & PSQ-The importance of need & 0.021 \\
& PSQ-Received support & 0.172 \\
\hline
\end{tabular}

* Correlation is significant at the 0.01 level (2-tailed).

PSQ: Postpartum Support Questionnaire

BAES: Breastfeeding Attitude Evaluation Scale

\section{Discussion}

In recent years, there has been so much emphasis on the role of postpartum social support in terms of encouraging breastfeeding and so may studies have drawn attention to the importance of supporting mothers in that regard (Aksakall et al., 2012). However, different cultures have different perspectives on postpartum social support and breastfeeding. This study examined, from the 
Karataş Okyay, E., Sunay, Z., Cengizhan, S. Ö., Kamalak, H., \& Uçar, T. (2022). The relationship between postpartum social support and attitudes towards breastfeeding: A cultural perspective. Journal of Human Sciences, 19(1), 17-26. doi:10.14687/jhs.v19i1.6050

standpoint of different cultural attitudes, the impact of social support for women after childbirth on the attitudes towards breastfeeding in three different Regions [Adiyaman (Region 1) in the Southeastern Anatolia Region, Kahramanmaraş (Region 2) in the Mediterranean Region and Malatya (Region 3) in the Eastern Anatolia Region)].

And it found that there was a significant difference between Regions in terms of the requirements of women for social support. Accordingly, women in the Region of Southeastern Anatolia (Region 1) needed the most support, while the opposite was true for women in the Mediterranean (Region 2) Region (Table 2, 3). Furthermore, it was found that there was a difference between Regions in terms of postpartum support; women in the Mediterranean Region (Region 2) got the highest level of support while new mothers in Southeastern Anatolia (Region 1) got the lowest amount of support (Table 2). These results show that in the Region of Southeastern Anatolia, the need for social support among women is high, but the level of social support actually received is low, nowhere near enough to meet the requirements of women. In Turkey, there is to our knowledge no study that offers a Region-based comparison of postpartum social support. One study conducted in the eastern part of the country indicated that the amount of support received by women after childbirth was nowhere near enough to meet their needs (Aksakall et al., 2012). Another study conducted in Eastern Anatolia also reported that women were far from getting the support they needed after childbirth (Türkoğlu et al., 2014). A study conducted abroad reported that the need for social support after childbirth could vary according to the role of women in society and gender (Albuja et al., 2017). In view of the results of that study, it may well be inferred that gender roles in Southeastern Anatolia or the social duties imposed on women might have forced them to seek more social support.

This study also found significant differences between Regions in terms of the attitudes of women towards breastfeeding; with the most favourable views held in Southeastern Anatolia (Region 1), and the least favourable ones held in Eastern Anatolia (Region 3) (Table 3). It is known that every society has its own unique perspective and norms and expectations concerning a woman's decision to start breastfeeding and continue to do so. The Turkey Demographic and Health survey 2018 revealed major differences between Regions. 72.7\% of mothers in Southeastern Anatolia started breastfeeding within the first hour, while that rate was $57.9 \%$ for the Central Anatolia Region (TNSA 2018). Even though there is no single study investigating Region-based differences, two different studies investigating breastfeeding self-efficacy showed that the average breastfeeding self-efficacy score of women was 47.8 in Southeastern Anatolia (Özkan et al., 2019) as opposed to 40.6 in Eastern Anatolia (Küçükoğlu \& Çelebioğlu, 2014). The results clearly indicate Region-based differences in terms of attitudes towards breastfeeding.

In the study, only in the Mediterranean Region (Region 2) was a significant correlation found between women's need for social support, social variables and attitudes towards breastfeeding (Table 4). Accordingly, women in the Mediterranean Region, asking for and getting more support after childbirth, have a more favourable attitude towards breastfeeding. In a qualitative study in Spain, another Mediterranean country, women reported that social support had a major impact on breastfeeding (Barona-Vilar et al., 2009). Also, there are a number of studies showing a connection between social support and breastfeeding attitudes in different cultures while other studies argue quite the opposite (Jalal, 2017; Srinivas et al., 2015; Twells, 2016). This study has reported similar results to these studies in terms of the relationship between social support and breastfeeding attitudes in the Mediterranean Region. These results suggest that there are many variables apart from social support that affect breastfeeding attitudes with different mechanisms in place in different societies to encourage breastfeeding. In many studies, it has been found that factors such as age, education level, family type, occupation, income level, smoking status, planned pregnancy and parity are also effective among the factors affecting breastfeeding attitude (Tezcan S., Koç G., 2015; Keddem et al. al. 2018; Ghasemi et al. 2019; Fernandes and Höfelmann, 2020). However, there are no studies showing the variation of these factors according to regions. 
Karataş Okyay, E., Sunay, Z., Cengizhan, S. Ö., Kamalak, H., \& Uçar, T. (2022). The relationship between postpartum social support and attitudes towards breastfeeding: A cultural perspective. Journal of Human Sciences, 19(1), 17-26. doi:10.14687/ihs.v19i1.6050

\section{Conclusion}

This study looked at the effects of postpartum social support for women on attitudes towards breastfeeding from different cultural perspectives, and found significant differences between the Regions. It also established that women in the Region of Southeastern Anatolia (Region 1) needed the most social support; that women in the Mediterranean Region (Region 2) received the highest level of social support and that women in the Region of Southeastern Anatolia (Region 1) had the most favourable attitudes towards breastfeeding. Moreover, only in the Mediterranean Region was there a significant relationship between social support and attitudes towards breastfeeding.

\section{Recommendations}

Women should be provided with ample support to help them continue breastfeeding after childbirth and families should be made more aware of the importance and urgency of the issue.

Health professionals should mobilise social support systems apart from merely providing postpartum physical care. And finally, cultural variations between different Regions should be taken into account when providing parents with postpartum social support and creating policies around breastfeeding.

\section{References}

Aksakallı, M., Çapık, A., Ejder Apay, S., Pasinlioğlu, T., \& Bayram, S. (2012). Loğusaların destek ihtiyaçlarının ve doğum sonu dönemde alınan destek düzeylerinin belirlenmesi. Psikiyatri Hemşireliği Dergisi, 3(3), 129-135. View Article: doi:http://dx.doi.org/10.12996/gmj.2018.08

Albuja, A. F., Lara, M. A., Navarrete, L., \& Nieto, L. (2017). Social support and postpartum depression revisited: the traditional female role as moderator among Mexican women. Sex role, 77(3-4), 209220. View Article: DOI: $10.1007 / \mathrm{s} 11199-016-0705-\mathrm{z}$

Annagür, B.B., Annagür, A. (2012). Relationship of Postpartum Mental Status with Breastfeeding. Current Approaches in Psychiatry, 4.3. View Article: https://doi.org/10.5455/cap.20120417

Area, Hacer. The effect of social support on mother-infant attachment in the postpartum period. PhD Thesis. Selcuk University Institute of Health Sciences; 2011.

Barona-Vilar, C., Escribá-Agüır, V., Ferrero-Gandía, R. (2009). A qualitative approach to social support and breast-feeding decisions. Midwifery, 25(2), 187-194. View Article: doi: 10.1016/j.midw.2007.01.013.

Çelebioğlu, A., Tezel, A., Özkan, H. (2006). Bebek Dostu Olan Ve Olmayan Hastanelerde Emzirme Durumunun Karşılaştırilmas1. Atatürk. Üniversitesi Hemşirelik Yüksekekoulu Dergisi, 9(3),44-51.

Ertürk, N. Adaptation of the postnatal support scale to the Turkish society. PhD Thesis. Master Thesis, Ege University, Izmir; 2007.

Fernandes, R. C., \& Höfelmann, D. A. (2020). Intention to breastfeed among pregnant women: association with work, smoking, and previous breastfeeding experience. Ciencia \& saude coletiva, 25, 1061-1072.

Ganle, J. K., \& Bedwei-Majdoub, V. M. (2020). Discontinuation Of Exclusive Breastfeeding In Ghana: A Longitudinal, One-Group Observational Study Of Postnatal Mothers With Children 0-6 Months Old. Journal of Human Lactation,36(3), 461-470. View Article: DOI:10.1177/0890334419871012journals.sagepub.com/home/jhl

Ghasemi, V., Simbar, M., Ghasemi, E., Ebadi, A., Kiani, Z., Keyghobad, F. M., \& Navand, P. H. (2019). Predictor factors of breastfeeding attitude in Iranian breastfeeding mothers: a cross-sectional study. International Journal of Pediatrics-Mashbad, 7(3), 9103-9113

Gölbaşı, Z., Koç, G. (2008). Breastfeeding behaviors of women in the first 6 months of postpartum and the effect of breastfeeding attitudes in prenatal period. Faculty of Health Sciences Nursing Journal, 16-31.

Güney, E., Uçar, T. (2018). The Effect of Body Image in Pregnancy on Breastfeeding Attitude and Postpartum Breastfeeding Process. Zeynep Kamil Medical Bulletin, 49 (1), 49-53. View Article: DOI: 10.16948/zktipb.338783

Hongo, H., Green, J., Shibanuma, A., Nanishi, K., \& Jimba, M. (2020). The influence of breastfeeding peer support on breastfeeding satisfaction among Japanese mothers: A randomized controlled trial. Journal of Human Lactation, 36(2), 337-347. View Article: https://doi.org/10.1177/0890334419869601

İnce, T., Kondolot, M., Yalçın, S.S., Yurdakök, K. (2010). Annelerin emzirme danışmanlı̆̆ı alma durumları. Cocuk Sağhğg ve Hastalkklar Dergisi. 53, 189-197. 
Karataş Okyay, E., Sunay, Z., Cengizhan, S. Ö., Kamalak, H., \& Uçar, T. (2022). The relationship between postpartum social support and attitudes towards breastfeeding: A cultural perspective. Journal of Human Sciences, 19(1), 17-26. doi:10.14687/jhs.v19i1.6050

Jackson, J. E., \& Hallam, J. (2020). Against all odds-why UK mothers' breastfeeding beyond infancy are turning to their international peers for emotional and informative support. Health care for women international, 1-17. View Article: DOI:10.1080/07399332.2020.1744147

Jalal, M. (2017). The relationship between psychological factors and maternal social support to breastfeeding process. Electronic physician, 9(1), 3561. View Article: DOI: 10.19082/3561

Keddem, S., Frasso, R., Dichter, M., \& Hanlon, A. (2018). The association between pregnancy intention and breastfeeding. Journal of Human Lactation, 34(1), 97-105.

Knaak, S. J. (2006). The problem with breastfeeding discourse. Canadian journal of public bealth, 97(5), $412-414$. View Article: DOI: $10.1007 /$ bf03405355

Kruse, L, Denk, E, Winter, L.F, Rotondo, F.M. (2006). Longitudinalpatterns of breastfeeding initiation. Materneland Child Health Journal Jan, 10(1),13-18. View Article: doi:10.1111/j.0730-7659.2005.00349.x

Kong, S. K., \& Lee, D. T. (2004). Factors influencing decision to breastfeed. Journal of advanced nursing, 46(4), 369-379. View Article: https://doi.org/10.1111/j.1365-2648.2004.03003.x

Küçükoğlu, S., Çelebioğlu, A. (2014). Determination of Postpartum Depression Symptoms and Breastfeeding Self-Efficacy Levels of Mothers Lying in the Newborn Clinic. Gümüshane University Journal of Health Sciences, 3(3), 921-922.

Leveno, K.J., FG, Cunningham. Williams birth information handbook. 21. 2004.

Logsdon, M. C., Usui, W., Birkimer, J. C., \& McBride, A. B. (1996). The postpartum support questionnaire: Reliability and validity. Journal of Nursing Measurement,4(2), 129-142. View Article: DOI:10.1891/1061-3749.4.2.129

Özer, A., Stone, F., Ekerbiçer, H.Ç. (2010). Knowledge and Behavior of Mothers with 0-6 Months of Baby on Breastfeeding and Breastfeeding. TAF Preventive Medicine Bulletin, 9(4).

Özkan, H. A. (2015). Emzirme tutumunu değerlendirme ölçeği. Kadın Sağhlğı Hemşireliği Dergisi, 2(1), 53-58.

Özkan, S. A., Bozkurt, A. M., Korkmaz, B., Yılmaz, G., \& Küçükkelkaç, D. Ş. (2019). The Relationship Between Depression and Breastfeeding Self-Efficacy in the Postpartum First Month. Hacettepe University Journal of Nursing Faculty, 6 (1), 28-35. View Article: https://doi.org/10.31125/hunhemsire.544119

Özkan, V.H.Ç., Durable P., Sharman, G., Balci, S. 42. Turkish Pediatrics Congress 2006; May 15-20, 2006; Antalya. Turkey: antalya.bebek friendly hospital with a feeding rate and factors affecting breastfeeding with breast milk feeding time; 111-155.

Srinivas, L.G., Benson, M., Worley, S.(2015). A Clinic-Based Breastfeeding Peer Counselor Intervention in an Urban, Low-Income Population: Interaction with Breastfeeding Attitude. Journal of Human Lactation, 31(1). View Article: DOI:https://doi.org/10.1177/0890334414548860.

Tezcan, S. (2005). Gebelerin Emzirmeye İlişkin Tutumları ve Emzirme Tutumunu Etkileyen Bazı Faktörler. Hacettepe Üniversitesi Hemşirelik Fakültesi Dergisi, 12(2), 1-13.

Turkey Demographic and Health Survey Main Report; (TNSA) 2018. Hacettepe University Institute of Population

Studies.Availablefrom:http://www.hips.hacettepe.edu.tr/tnsa2018/rapor/sonuclar_sunum.pdfdu.tr /tnsa2018/rapor/sonuclar_sunum.pdf

Türkoğlu, N., Sis, C..A., Pasinlioğlu, T. (2014). Determination of Postpartum Social Support Needs and Support Received. Journal of Education and Research in Nursing, 11 (1), 18-24.

Twells, K., Midodzi, W.K., Ludlow, V.,Goodridge, J.M., Burrage, L., Gill, N., Halfyard, B. (2016). Assessing Infant Feeding Attitudes of Expectant Women in a Provincial Population in Canada: Validation of the Iowa Infant Feeding Attitude Scale. Journal of Human Lactation, 32(3). View Article: DOI:https://doi.org/10.1177/0890334414559647. 